(C) Усиченко О. В., 2021

https://orcid.org/0000-0002-7314-7914

DOI 10.34142/23128046.2021.50.15

О. В. Усиченко

\title{
ФОРМУВАННЯ ІНТЕЛЕКТУАЛЬНО-ОЦІНЮВАЛЬНИХ УМІНЬ ЗДОБУВАЧІВ ПРОФЕСІЙНӦ̈ (ПРОФЕСІЙНО-ТЕХНІЧНОЇ) ОСВІТИУ ПРОЦЕСІ НАВЧАННЯ
}

У статті доведено актуальність проблеми формування інтелектуально-оцінювальних умінь здобувачів професійной (професійнотехнічної) освіти. Установлено, щуо очінювальні вміння здобувачів освіти доцільно розглядати у взаємозв'язку з інтелектуальними, оскільки редукція вмінь до спеціальних (предметних) умінь не враховує інтелектуальну спрямованість оцінювальної діяльності, щуо «збіднює спектр методичних можливостей формування вмінь самоконтролю $i$ самооцінювання». На підставі узагальнення різних підходів учених щзодо тлумачення суті та структури інтелектуальних та оцінювальних умінь визначено авторську позицію до розкриття вказаних характеристик в інтеграції означених умінь. Інтелектуально-оцінювальні вміння визначено як здатність учнів, котра виражається в уміннях мислити, порівнювати, структурувати об'єкти та інформацію, аналізувати класифікувати та узагальнювати отримані дані та результати, вміння виділяти головне $і$ концентрувати свою увагу на ньому, вміння мотивувати свою діяльність та прогнозувати ї результати; отримувати, переробляти та застосовувати інформачію 3 різних джерел; співвідносити отримані результати з поставленою метою; здійснювати самоконтроль $i$ самооиінку. Стверджується, щзо сформованість інтелектуальних умінь надаватиме можливість учням ефективно опрацьовувати інформацію та оперативно вирішувати пізнавальні та навчально-професійні завдання, сформованість оцінювальних умінь сприятиме одночасно об 'єктивному обробленню доступної інформачї, результатів навчання тощчо.

На підставі теоретичного аналізу наукових джерел було виділено групи інтелектуально-оцінювальних умінь здобувачів професійной (професійнотехнічної) освіти: пізнавально-логічні; інтелектуально-інформаційні; перетворювально-творчі; рефлексивно-самооцінювальні.

На підставі вивчення різних теорій та конц̧епції формування умінь автором визначено етапи технологї формування інтелектуальнооцінювальних умінь учнів закладів професійної (професійно-технічної) освіти: мотиваційно-настановчий, когнітивно-розвивальнй, операційнодіяльнісний, рефлексивно-коригувальний. 
Ключові слова: здобувач професійної (професійно-технічної) освіти, уміння, інтелектуально-оцінювальні вміння, формування, етап.

Usychenko O.V. Formation of intellectual and evaluative skills of students of professional (professional-technical) education in the learning process. The article proves the relevance of the problem of forming the intellectual and evaluative skills of applicants for professional (vocational) education. It is proved that it is reasonable to consider the evaluative skills of education applicants in the relationship with the intellectual, because the reduction of skills in the special (subject) skills does not take into account the intellectual orientation of the evaluative activity, "impoverishes the range of methodological opportunities for forming the skills of self-control and self-evaluation".Based on the summary of different approaches of students to the understanding of the essence and structure of intellectual and evaluative skills the author's position to the disclosure of these characteristics in the integration of these skills has been determined.

Intellectual and evaluative skills are defined as the ability of students, which is expressed in the ability to think, compare, structure objects and information, ability to analyze classify and summarize obtained data and results, the ability to identify and focus their attention on the main thing, the ability to motivate their activities and predict their results; receive, process and use information from different sources; correlate the obtained results with the set goal; perform selfmonitoring and self-evaluation). It is claimed that the formation of intellectual skills will enable students to effectively process information and promptly solve cognitive and educational-professional tasks, formation of evaluative skills will contribute to simultaneous active processing of available information, learning results, etc.

Based on the theoretical analysis of scientific sources, the following groups of intellectual and evaluative skills of students of professional (professionaltechnical) education were identified: cognitive-logical; intellectual-informational; transformational-creative; reflexive-self-evaluative.

Based on the study of different theories and concepts of skill formation the author has identified the stages of the technology of forming intellectual and evaluative skills of the students of vocational (vocational-technical) education institutions: motivational-instructional, cognitive-developmental, operationactivityy, reflexive-corrective.

Key words: student of vocational (vocational-technical) education, skills, intellectual-evaluative skills, formation, stage.

Вступ. Необхідність модернізації змісту навчання учнів закладів професійної (професійно-технічної) освіти вимагає розробки нових підходів, спрямованих на забезпечення розвитку культури мислення здобувачів освіти. Така необхідність зумовлена виникненням нових потреб і категорій життя, серед яких визначальними $є$ інтеграція й глобалізація соціальних, економічних 
i культурних процесів, входження України у світовий економічний та інформаційний простір, у часовому вимірі якого вміння самостійно і активно діяти, приймати рішення, гнучко адаптуватися до швидкозмінних умов життя, мислити відповідно до норм і вимог динамічної культурної реальності набуває важливого значення.

Вивчення педагогами, психологами, філософами різних аспектів культури мислення дає можливість визначити певні шляхи активізації інтелектуальнооцінювальної діяльності учнів у процесі навчання. Отже, завдання розвитку культури мислення нерозривно пов'язане із формуванням в учнів ключових компетентностей, серед яких у контексті нашого дослідження провідне місце займають інтелектуально-оцінювальні вміння. Зміст означених умінь співвідноситься із культурою мислення у площині вирішення стратегічних завдань сучасних закладів професійної (професійно-технічної) освіти навчити учнів інтелектуально-оцінювальної діяльності. На цьому наголошували у своїх наукових розвідках І. Зимня, Н. Менчинська, О. Савченко, В. Паламарчук, А. Хуторський та інші вчені. Ці завдання можуть бути вирішеними за умови формування інтелектуально-оцінювальних умінь учнів, які забезпечують діяльнісний характер навчання.

Розв’язання проблеми формування інтелектуально-оцінювальних умінь можливе за умови комплексного підходу до вивчення складових процесу пізнання, об'єднання визначальних компонентів інтелектуально-оцінювальної діяльності (мотиваційно-ціннісного, змістового, логіко-рефлексивного) у єдиний предмет вивчення (Marchenko, 2006).

Мета та завдання. На підставі аналізу наукової літератури з'ясувати суть і зміст інтелектуально-оцінювальних умінь учнівзакладів професійної (професійно-технічної) освіти в процесі навчання; визначити етапи формування означених умінь.

Методи дослідження. Під час наукового пошуку використовувався комплекс методів дослідження: теоретичних (теоретичне узагальнення наукових ідей i поглядів, викладених у філософській, педагогічній, психологічній літературі 3 проблеми дослідження; аналіз педагогічного досвіду, причинно-наслідковий аналіз результатів наукових досліджень); емпіричних (спостереження, анкетування, тестування, бесіда, самооцінювання учнів, експертна оцінка).

Результати. У дослідженні проблеми формування інтелектуальнооцінювальних вмінь (далі - IOB) учнів закладів професійної (професійнотехнічної) освіти (далі - ЗППТО) виходимо із загального розуміння суті поняття «уміння» як здатності здобувача освіти проводити певну діяльність на основі отриманих знань і навичок, завершальну стадію формування дії, 
оволодіння якою дозволяє переключатися 3 одного способу дії на інший, урізноманітнювати прийоми діяльності (Popova \& Tamozhska, 2016).

Інтелектуальні вміння в дидактиці вчені (Ю. Бабанський, І. Лернер, В. Лозова, В. Паламарчук та ін.) зазвичай розглядають як уміння мислити, порівнювати, структурувати об’єкти та інформацію, аналізувати класифікувати та узагальнювати отримані дані та результати, вміння виділяти головне і концентрувати свою увагу на ньому, вміння мотивувати свою діяльність та прогнозувати їі результати (Khorunzha, 2009).

Водночас нагальною проблемою постає проблема верифікації інформації. Стрімкий розвиток інформаційних технологій та суцільна інформатизація всіх сфер суспільного життя створили умови, в яких здійснення контролю правдивості та достовірності інформації $\epsilon$ майже неможливим. Тобто здобувач професійної (професійно-технічної) освіти опиняється в умовах, коли, з одного боку, він має майже миттєвий доступ до необмеженої кількості інформації, a, 3 іншого, - він повинен не лише визначати корисність та необхідність саме цієї інформації для вирішення навчальних i навчально-професійних завдань, а й швидко і безпомилково визначити правдивість та достовірність отриманих даних (Usichenko, 2020). У такому контексті прийнятним є визначення інтелектуальних умінь учнів як сукупність дій і операцій з отримання, переробки та застосування інформації в освітній діяльності (Sharun, 2013).

На думку багатьох учених (Т. Барановська, Н. Нєстерова, I. Пронічева, А. Хмельницька та ін.), оцінювальні вміння - це якість особистості, що виражається в уміннях: поставити мету своєї діяльності, домагатися іiі здійснення власними силами; співвідносити отримані результати з еталоном (здійснювати самоконтроль) i оцінювати результат своєї діяльності відповідно до критеріїв оцінювання (здійснювати самооцінку), намічаючи шляхи корекції результату.

Узагальнюючи різні підходи вчених щодо тлумачення суті інтелектуальних та оцінювальних умінь, $\boldsymbol{I O B}$ визначили як здатність учнів, яка виражається в уміннях мислити, порівнювати, структурувати об'єкти та інформацію, аналізувати класифікувати та узагальнювати отримані дані та результати, вміння виділяти головне і концентрувати свою увагу на ньому, вміння мотивувати свою діяльність та прогнозувати ii результати; отримувати, переробляти та застосовувати інформацію 3 різних джерел; співвідносити отримані результати 3 поставленою метою; здійснювати самоконтроль і самооцінку. 
У цілому IOB включають чималу кількість різнопланових процесів інтелектуально-оцінювальної діяльності, що потребує їх класифікації. У структурі вказаних умінь нами виокремлено такі їх групи:

- пізнавально-логічні;

- інтелектуально-інформаційні;

- перетворювально-творчі;

- рефлексивно-самооцінювальні.

До пізнавально-логічних відносимо такі уміння: мотивувати свою діяльність; уважно сприймати інформацію; здійснювати інтелектуальномисленнєві операції (аналіз, синтез, порівняння, узагальнення, зіставлення, моделювання, конкретизацію, систематизацію тощо); визначати суть поняття; логічно осмислювати навчальний матеріал, виділяючи в ньому головне; раціонально запам'ятовувати; аналізувати навчальну ситуацію і здійснювати організацію продуктивної самостійної навчальної діяльності (у тому числі використовуючи засоби ІКТ).

Сукупність інтелектуально-інформаційних умінь визначається такими вміннями:

- отримувати інформацію (розуміти завдання в різних формулюваннях і контекстах; застосовувати інструментарій для підготовки та отримання інформації; знаходити необхідну інформацію в різних джерелах; тривалий час займатися пошуком тематичної інформації);

- переробляти отриману інформацію (систематизувати запропоновану або самостійно підібрану інформацію за заданими ознаками; знаходити помилки в одержуваній інформації та вносити пропозиції щодо їх виправлення; встановлювати асоціативні та практично доцільні зв'язки між інформаційними повідомленнями; виокремлювати головне в інформаційному повідомленні; застосовувати інструментарій для передачі інформації; оцінювати отриману інформацію з естетичних та морально-етичних позицій);

- застосовувати інформацію у професійній діяльності (застосовувати інструментарій для використання інформації під час вирішення навчально-професійних завдань; приймати оптимальне рішення або варіативні рішення в різних ситуаціях професійного характеру (Sharun, 2013).

Перетворювально-творчі вміння передбачають наявність таких умінь: переносити вміння в нову ситуацію, формулювати проблеми, робити припущення, спростовувати хибне, знаходити варіанти розв'язання проблеми, формулювати пізнавальні запитання; прогнозувати результати подальшої діяльності, спираючись, у тому числі, на можливості апаратнопрограмних засобів, які залучаються до навчальної діяльності.

Групу рефлексивно-самооцінювальних умінь утворюють такі уміння: критично оцінювати результати власної діяльності на основі аналізу 
інформації (у тому числі, яка відображається засобами IКТ); приймати рішення на основі аналізу й оцінки наукових фактів, які вивчаються у певному навчальному курсі, а також інформації, що отримується в процесі самоосвітньої діяльності за допомогою засобів IKT.

Наша концепція формування IОВ учнів у процесі навчання в ЗППТО визначається такими ключовими положеннями:

1. Оскільки проблема формування вмінь у межах загальної концепції мислення розглядається як опосередковане узагальнене відображення об'єктивних суттєвих зв'язків дійсності, що здійснюється через операції аналізу і синтезу, процеси абстрагування й узагальнення, логічним $є$ твердження: щоб розумова дія стала об’єктом спеціального пізнання, важливо побудувати розумову діяльність здобувача освіти в чіткій відповідності зі структурою розумових дій, що формуються, дотримуючись принципу єдності свідомості та діяльності (Н. Недодатко) (Nedodatko, 2002).

2. $\quad$ При проєктуванні технології формування IOB в учнів ЗППТО доцільно враховувати такі теорії та концепції формування вмінь: концепція формування інтелектуальних умінь i навичок (Є. Кабанова-Меллер, Н. Менчинська); теорія поетапного формування розумових дій (П. Гальперін, Н. Тализіна); концепція трансформації досвіду в уміння (К. Платонов, Д. Толлінгерова) (Galperin, 2005; Lozova, 2010;Popova \& Tamozhska, 2016).

Вивчення вказаних теорій і концепцій дали можливість у формуванні IOB учнів ЗППТО виокремити такі стадії: 1) формування мотиваційної основи, тобто мотивації дії; 2) складання алгоритму орієнтованої основи дії,

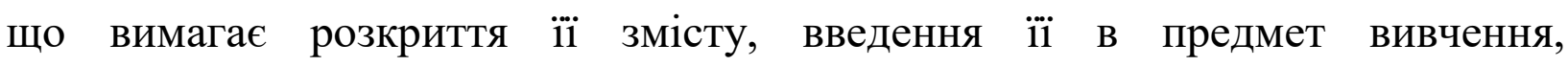
демонстрацію означеного алгоритму з виконання операцій, які входять в дію (орієнтовані, виконавчі, контрольні); 3) формування дії в матеріальному вигляді, тобто виконання дії у зовнішній, матеріальній (або матеріалізованій) формі $з$ розгортанням усіх вхідних до неї операцій); 4) формування дії у голосовій соціалізованій мові; 5) формування дії у зовнішній мові «про себе», при цьому дія, прийнявши розумову форму, швидко починає скорочуватися i автоматизуватися; 6) формування дії у внутрішній мові, тобто дія набуває автоматичного протікання, стає недоступною для самоспостереження).

На підставі вказаних положень автором визначено етапи технології формування інтелектуально-оцінювальних умінь учнів закладів професійної (професійно-технічної) освіти: мотиваційно-настановчий, когнітивнорозвивальнй, операційно-діяльнісний, рефлексивно-коригувальний.

Обговорення. Проведений концептуально-термінологічний та структурно-феноменологічний аналіз дав підстави свідчити, що характерним для більшості класифікацій умінь є те, що їх обов'язковим і невід'ємним 
компонентом $\epsilon$ інтелектуальні уміння. Повною мірою погоджуємося зО. Соколюк, яка вважає, що редукція вмінь до спеціальних (предметних) умінь не враховує інтелектуальну спрямованість оцінювальної діяльності, що, у свою чергу, «збіднює спектр методичних можливостей формування вмінь самоконтролю і самооцінювання та обмежує область діагностичного інструментарію, який можна використовувати для оцінювання рівня їх сформованості» (Sokoliuk, 2016).

3 огляду на зазначене, можна стверджувати, що оцінювальні вміння відносяться до інтелектуальних умінь i $\epsilon$ складовою системи загальнонавчальних умінь, а дії оцінювання мають надситуативний характер i можуть бути визначені як «дії 3 діями», а не 3 предметами. Отже, оцінювальні вміння в учнів ЗППТО доцільно й необхідно розглядати у взаємозв’язку з інтелектуальними, тобто постає питання про формування в учнів інтелектуально-оцінювальних умінь. Саме в такому разі можна досягти оптимального результату щодо підвищення якості навчання здобувачів освіти. У той час, як сформованість інтелектуальних умінь надаватиме можливість учням ефективно опрацьовувати інформацію та оперативно вирішувати пізнавальні та навчально-професійні завдання, сформованість оцінювальних умінь сприятиме одночасно об'єктивному обробленню доступної інформації, результатів навчання тощо.

Висновки. Реалії динамічних перетворень сучасного суспільства зумовлюють об’єктивну потребу оптимізації процесу навчання учнів у ЗППТО, що, у свою чергу, актуалізує проблему формування IOB у здобувачів освіти.

Узагальнення різних підходів учених щодо тлумачення суті та структури інтелектуальних та оцінювальних умінь дало змогу визначити суть інтелектуально-оцінювальних умінь як здатність учнів, котра виражається в уміннях мислити, порівнювати, структурувати об'єкти та інформацію, аналізувати класифікувати та узагальнювати отримані дані та результати, вміння виділяти головне i концентрувати свою увагу на ньому, вміння мотивувати свою діяльність та прогнозувати їі результати; отримувати, переробляти та застосовувати інформацію 3 різних джерел; співвідносити отримані результати 3 поставленою метою; здійснювати самоконтроль i самооцінку.

Структуру IOB здобувачів професійної (професійно-технічної) освіти складають такі групи вмінь, як: пізнавально-логічні; інтелектуальноінформаційні; перетворювально-творчі; рефлексивно-самооцінювальні.

Вивчення різних теорій та концепції формування умінь дало можливість виокремити етапи технології формування IOB учнів ЗППТО: мотиваційно- 
настановчий, когнітивно-розвивальнй, операційно-діяльнісний, рефлексивнокоригувальний.

Аналіз сучасного стану проблеми формування IOB у здобувачів професійної (професійно-технічної) освіти у процесі навчання дає підстави стверджувати, що вона має багато недостатньо вивчених аспектів, що потребує подальших спеціальних досліджень.

\section{ЛІТЕРАТУРА:}

Гальперин П. Я. Лекции по психологии: учеб. пособ. для студентов вузов. М. : КДУ, 2005. $400 \mathrm{c}$.

Марченко О. В. Формування культури мислення старшокласників засобами дослідницької діяльності: ареф. ... дис. канд педа наук : 13.00.09 «Теорія навчання». К., 2006. 20 c.

Лекції з педагогіки вищої школи : навчальний посібник / за редакцією В.І. Лозової. 2-е вид., доп. і випр. Х. : «ОВС», 2010. 480 с.

Недодатко Н. Технологія формування навчально-дослідницьких умінь школярів. Рідна школа. 2002. № 6 (869). С. 21-24.

Попова О. В., Таможська I. В. Формування вмінь ділового спілкування майбутніх фахівців технічного профілю (на матеріалі вивчення соціально-гуманітарних дисциплін) : монографія. Дніпропетровськ : Середняк Т. К., 2016. 234 с.

Соколюк О. М. Розвиток контрольно-оцінювальних умінь старшокласників у процесі навчання фізики в умовах комп'ютерно орієнтованого середовища: автореф. дис. ... канд. пед. наук : 13.00 .02 «Теорія та методика навчання (фізика)». К., 2010. 20 с.

Усиченко О.В. Інтелектуально-оцінювальні вміння як важлива складова професійної компетентності майбутніх фахівців кухарської справи.Психолого-педагогічні проблеми вищої і середньої освіти в умовах сучасних викликів: теорія і практика : матеріали IV Міжнар. наук.-практ. конф. (м. Харків, 12 грудня 2019 р.) / Харк. нац. пед. ун-т ім. Г. С. Сковороди. Х., 2020. С. 392-395.

Хорунжа Л. Л. Формування інтелектуальної мобільності старшокласників у навчальному процесі загальноосвітньої школи : автореф. дис. ... канд пед наук : 13.00 .09 «Теорія навчання». Х., 2009, 20 с.

Шарун Ю.Ф. Проблема формування інтелектуальних умінь як об'єкт дослідження науковців другої половини ХХ століття. Засоби навчальної та науково-дослідної роботи. 2013. Вип. 40. С. 245-251. URL: http://nbuv.gov.ua/UJRN/znpkhnpu_zntndr_2013_40_29

\section{REFERENCES:}

Galperin, P. Ya. (2005) Lektsii po psihologii [Lectures on psychology]: ucheb. posob. dlya studentov vuzov. M. : KDU, 2005. 400 s. (in Russian).

Marchenko, O. V. (2006) Formuvannia kultury myslennia starshoklasnykiv zasobamy doslidnytskoi diialnosti [Formation of culture of thinking of senior pupils by means of research activity]: aref. ... dis. kand peda nauk : 13.00 .09 «Teoriia navchannia». Kyiv, 20 s. (in Ukranian).

Lozova, V.I. (Ed.) (2010) Lektsii z pedahohiky vyshchoi shkoly [Lectures on the pedagogy of higher education] : navchalnyi posibnyk. 2-e vyd., dop. i vypr. H. : «OVS», 2010. $480 \mathrm{~s}$. (in Ukranian).

Nedodatko, N. (2002) Tekhnolohiiy formuvannia navchalno-doslidnytskykh umin shkoliariv. [Technology of formation of educational research skills of schoolchildren]. Ridna shkola. \# 6 (869). S. 21-24. (in Ukranian). 
Popova, O. V. \& Tamozhska, I. V. (2016) Formuvannia vmin dilovoho spilkuvannia maibutnikh fakhivtsiv tekhnichnoho profiliu [Formation of business communication skills of future specialists of technical profile] (na materiali vyvchennia sotsialno-humanitarnykh dystsyplin) : monohrafiia. Dnipropetrovsk : Seredniak T. K., 234 s. (in Ukranian).

Sokoliuk, O. M. (2010) Rozvytok kontrolno-otsiniuvalnykh umin starshoklasnykiv u protsesi navchannia fizyky v umovakh kompiuterno orientovanoho seredovyshcha [Development of control and evaluation skills of senior pupils in the process of physics training in a computer-oriented environment]: avtoref. dis. ... kand. ped. nauk : 13.00.02 «Teoriia ta metodyka navchannia (fizyka)». Kyiv, 20 s. (in Ukranian).

Usichenko, O. V. (2020) Intelektualno-otsiniuvalni vminnia yak vazhlyva skladova profesiynoi kompetentnosti maybutnikh fakhivtsiv kukharskoi spravy. [Intelligent-evaluation skills as an important component of professional competence of future specialists of the Cook]. Psiholoho-pedahohichni problemy vishchoi $i$ serednoi osvity $v$ umovakh suchasnykh vyklykiv: teoriia i praktyka : materialy IV Mizhnar. nauk.-prakt. konf. (m. Kharkiv, 12 hrudnia 2019 r.) / Khark. nats. ped. un-t im. H. S. Skovorody. Kharkiv, S. 392-395 (in Ukranian).

Khorunzha, L. L. (2009) Formuvannia Intelektualnoi mobilnosti starshoklasnykiv u navchalnomu protsesi zahalnoosvitnoi shkoly [Forming intellectual mobility of senior pupils in the educational process of a secondary school]: avtoref. dis. ... kand ped nauk : 13.00 .09 «Teoriia navchannia». Kharkiv, 20 s. (in Ukranian).

Sharun, $\mathrm{Yu}$. $\mathrm{F}$.

Problemaformuvanniaintelektualnykhuminyakobektdoslidzhennianaukovtsivdrugoipolov ynyXXstolittia. [Problem of the formation of intellectual skills as an object of research of scientists of the second half of the twentieth century]. Zasoby navchalnoi ta naukovodoslidnoi roboty. Vyp. 40. S. 245 (in Ukranian).

\section{Інформація про авторів: Усиченко Олена Вікторівна,}

ORCID: http://orcid.org.//0000-0002-73147914, аспірантка кафедри освітології та інноваційної педагогіки, Харківський національний педагогічний університет імені Г. С. Сковороди, вул. Алчевських, 29, Харків, Україна, 61002

e-mail: elena.usichenko@ukr.net

\section{Information about the authors:} Usychenko OlenaViktorivna, ORCID: http://orcid.org.//0000-0002-73147914, postgraduate student of the Department of Education and Innovative Pedagogy, H. S. Skovoroda Kharkiv National Pedagogical University, Alchevskykh st., 29, Kharkiv, Ukraine, 61002

e-mail: elena.usichenko@ukr.net

Цитуйте цю статтю як: Усиченко О. В.Формування інтелектуально-оцінювальних умінь здобувачів професійної (професійно-технічної) освітиу процесі навчання.Теорія та методика навчання та виховання. 2021. № 50. С.165-173.

DOI: $10.34142 / 23128046.2021 .50 .15$

Дата надходження статті до редакції: 17.03.2021 p.

Стаття прийнята до друку: 01.04.2021 p. 